\title{
Preparation, characterization, bioactive and metal uptake studies of alginate/phosphorylated chitin blend films
}

\author{
R. Jayakumar ${ }^{\mathrm{a}, \mathrm{c}, *}$, M. Rajkumar ${ }^{\mathrm{b}}$, H. Freitas ${ }^{\mathrm{b}}$, N. Selvamurugan ${ }^{\mathrm{c}}$, S.V. Nair ${ }^{\mathrm{c}}$, T. Furuike $^{\mathrm{c}}$, H. Tamura $^{\mathrm{a}, * *}$ \\ a Faculty of Chemistry, Materials and Bioengineering and High Technology Research Centre, Kansai University, Suita, Osaka 564-8680, Japan \\ b Centre for Functional Ecology, Department of Botany, University of Coimbra, Coimbra 3000-455, Portugal

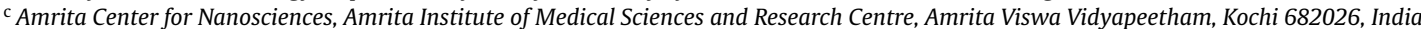

\section{A R T I C L E I N F O}

\section{Article history:}

Received 13 October 2008

Received in revised form 28 October 2008

Accepted 28 October 2008

Available online 5 November 2008

\section{Keywords:}

Biomaterials

Sodium alginate

Phosphorylated chitin

Biomineralization studies

\begin{abstract}
A B S T R A C T
Alginate/phosphorylated chitin (P-chitin) blend films were prepared by mixing of $2 \%$ of alginate and Pchitin in water and then cross-linked with $4 \% \mathrm{CaCl}_{2}$ solution. The blended films were characterized by FT-IR. Then, the bioactivity of blend films was studied by biomimetic method in simulated body fluid solution (SBF) for 7, 14 and 21 days. After 7, 14 and 21 days and films were characterized by FT-IR and SEM studies. The SEM and FT-IR studies showed that the hydroxyapatite was formed on the surface of the blend films after 7, 14 and 21 days in the SBF solution. These studies confirmed that the alginate/P-chitin blend films are bioactive. Furthermore, the adsorption of $\mathrm{Ni}^{2+}, \mathrm{Zn}^{2+}$ and $\mathrm{Cu}^{2+}$ onto alginate/P-chitin blend films has been investigated. The parameters studied include the $\mathrm{pH}$, contact time, and initial metal ion concentrations. The maximum adsorption capacity of alginate/P-chitin blend films for $\mathrm{Ni}^{2+}, \mathrm{Zn}^{2+}$ and $\mathrm{Cu}^{2+}$ at pH 5.0 was found to be $5.67,2.85$ and $11.7 \mathrm{mg} / \mathrm{g}$, respectively. These results suggest that alginate/P-chitin blend films-based technologies may be developed for water purification and metal ions separation and enrichment.
\end{abstract}

(c) 2008 Elsevier B.V. All rights reserved.

\section{Introduction}

Alginate and chitin are among the most versatile marine biopolymers. Alginates are a family of linear polysaccharides, which contain varying amounts of 1,4 -linked $\beta$-D-mannuronic acid and $\alpha$-L-glucuronic acid residues. Alginate possesses mucoadhesive properties with low toxicity and low immunogenicity, which enabled as a matrix for the entrapent and delivery of a variety of proteins and cells [1,2]. Chitin, a natural abundant polysaccharide, is known to be the $\beta$-1,4-glycan of $N$-acetyl-D-glucosamine. Chitin is also known to be biodegradable polymer in nature and in the animal body $[3,4]$ and to be a low toxicity. Chitin and its derivatives have great potential application in the areas of biotechnology, biomedicine, food ingredients, and cosmetics. Chitin and its derivatives are also capable of adsorbing a number of metal ions. Due to their high nitrogen content and porosity, chitin-based sorbents have exhibited relatively high sorption capacities and kinetics foremost heavy metals [5-7].

\footnotetext{
* Corresponding author at: Center for Nanosciences, Amrita Institute of Medical Sciences and Research Centre, Amrita Viswa Vidyapeetham, Kochi 682026, India. Tel.: +91 484 2801234; fax: +91 4842802020

** Corresponding author. Tel.: +91 484 2801234; fax: +91 4842802020.

E-mail addresses: jayakumar77@yahoo.com (R. Jayakumar), tamura@ipcku.kansai-u.ac.jp (H. Tamura).
}

Chitin and chitosan have tremendous applications in the biomedical field due to their good biocompatibility, biodegradability, and capacity to form membranes, beads, fibers, scaffold and gels [8-12]. Phosphorylated chitin (P-chitin) is a water-soluble derivative of chitin and it has been reported as good biomedical material [8]. P-chitin is biocompatible, bioabsorable and osteoconductive material and good be a bone repair material [8]. Both alginate and P-chitin are anionic polymers and these polymers can easily cross-link with $\mathrm{Ca}^{2+}$. In this paper, we report the preparation, characterization, bioactivity studies and the metal uptake $\left(\mathrm{Ni}^{2+}\right.$, $\mathrm{Zn}^{2+}$ and $\mathrm{Cu}^{2+}$ ) behavior of the P-chitin/alginate blends in details.

\section{Materials and methods}

\subsection{Materials}

Sodium alginate (Ducalgin NSPH2: $1000 \pm 100 \mathrm{cp}$ ) was provided by Kibun Food Chemipha. $\alpha$-Chitin was received from KYOWA TECNOS Co. Ltd. All other materials used were of analytical grade.

\subsection{Synthesis of P-chitin}

P-chitin was prepared by the following method [13-15]. In briefly, $5.0 \mathrm{~g}$ of chitin was added to the $\mathrm{P}_{2} \mathrm{O}_{5}(62.5 \mathrm{~g}), \mathrm{H}_{3} \mathrm{PO}_{4}(20 \mathrm{ml})$, $\mathrm{Et}_{3} \mathrm{PO}_{4}(20 \mathrm{ml})$ and hexanol $(25 \mathrm{ml})$ mixture in a $100 \mathrm{ml}$ flask and 

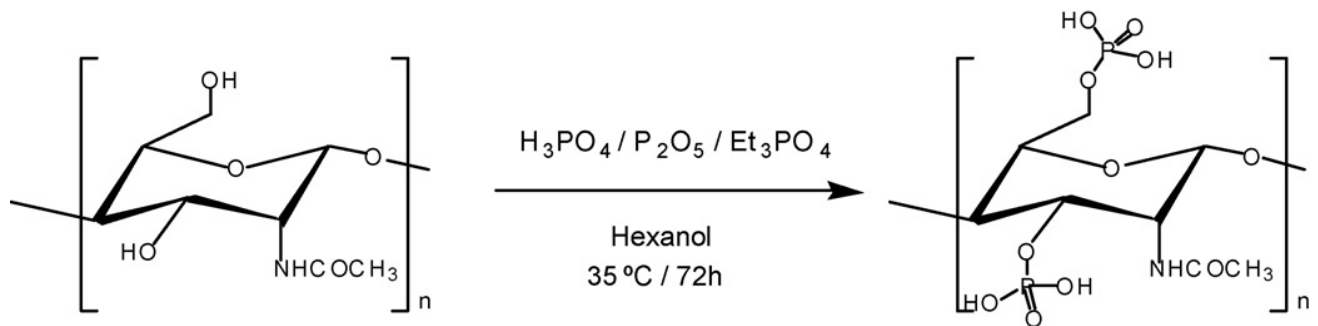

Scheme 1. Synthesis of P-chitin.

the mixture was stirred continuously for $72 \mathrm{~h}$ at $35^{\circ} \mathrm{C}$. After $72 \mathrm{~h}$ the reaction mixture was poured into excess methanol for precipitation. The precipitate was filtered and washed with methanol and then dried in vacuum oven at $37^{\circ} \mathrm{C}$ for $24 \mathrm{~h}$. The yield of the product was $70 \%$. The degree of substitution of phosphorous was found to be 1.87. The synthesis of P-chitin was shown in Scheme 1.

\subsection{Preparation of alginate/P-chitin blend films}

$0.2 \mathrm{~g}$ alginate and $0.2 \mathrm{~g}$ of P-chitin was dissolved in 20 of water and then cross-linked with $4 \% \mathrm{CaCl}_{2}$ solution. The prepared blend films were washed with methanol to remove the excess of $\mathrm{CaCl}_{2}$ solution. Then, the prepared films were dried at room temperature. Fig. 1 shows the cross-linking mechanism of alginate and P-chitin.

\subsection{Preparation of SBF solution}

The SBF solution was prepared by the following method [16], and contained $15 \mathrm{ml}$ of each of the following: $2.74 \mathrm{moll}^{-1}$ $\mathrm{NaCl}, 0.06 \mathrm{moll}^{-1} \mathrm{KCl}, 0.05 \mathrm{moll}^{-1} \mathrm{CaCl}_{2}, 0.03 \mathrm{moll}^{-1} \mathrm{MgCl}_{2}$, $0.0895 \mathrm{moll}^{-1} \mathrm{NaHCO}_{3}, 0.02 \mathrm{moll}^{-1} \quad \mathrm{~K}_{2} \mathrm{HPO}_{4}$ and $0.01 \mathrm{moll}^{-1}$ $\mathrm{Na}_{2} \mathrm{SO}_{4}$. These were added $200 \mathrm{ml}$ volumetric flask along with $25 \mathrm{ml}$ of each of $0.4 \mathrm{moll}^{-1}$ Tris hydroxy methyl methane amine and $0.36 \mathrm{moll}^{-1}$ of $\mathrm{HCl}$. The $\mathrm{pH}$ of the solution was adjusted to 7.4 by adding a few drops of $\mathrm{HCl}$ with the remainder of the volume being distilled water.

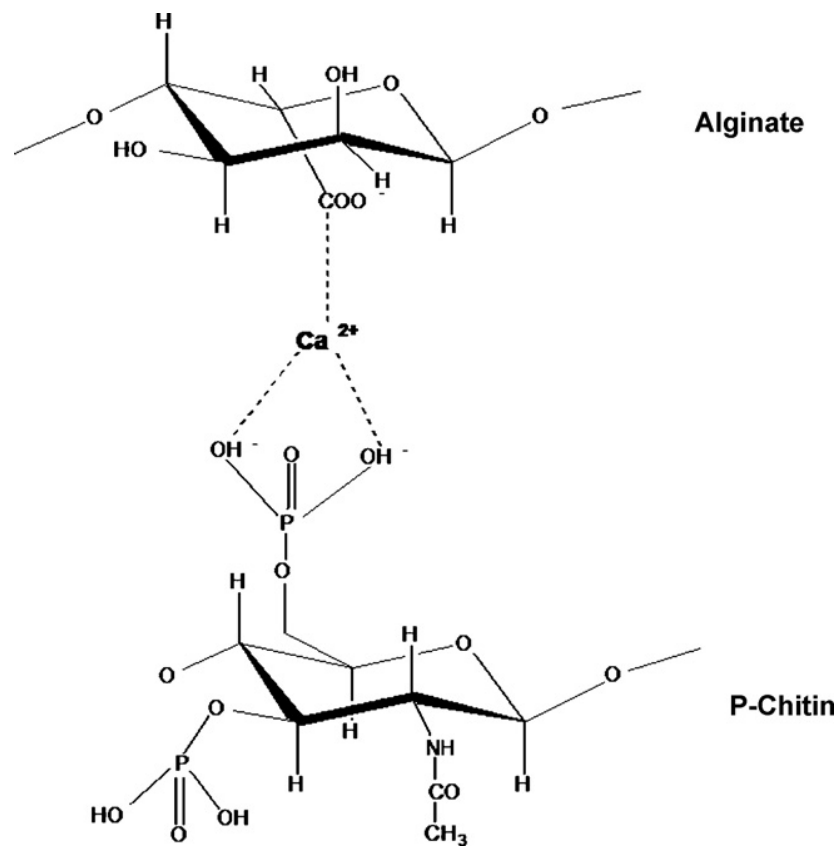

Fig. 1. Cross-linking mechanism of alginate/P-chitin with $\mathrm{Ca}^{2+}$.

\subsection{Bioactivity studies of alginate/P-chitin blend films}

The bioactivity studies of alginate/P-chitin blend films were carried out by biomimetic method with $1.5 \times$ SBF solutions. The blended films were vertically suspended in plastic jars with cotton threads and $30 \mathrm{ml}$ of $1.5 \times$ SBF solutions was added. The SBF solution was replaced each day. Samples were retrieved after 7, 14 and 21 days of soaking at $37^{\circ} \mathrm{C}$. The retrieved samples were thoroughly rinsed with distilled water and dried at $65^{\circ} \mathrm{C}$ before performing various characterization studies.

\subsection{Metal adsorption experiments}

Batch adsorption experiments were conducted by placing a $50 \mathrm{mg}$ of alginate/P-chitin blend films in $50 \mathrm{ml}$ reagent bottles containing $25 \mathrm{ml}$ of aqueous solution of metal ions $\mathrm{Ni}^{2+}, \mathrm{Zn}^{2+}$ and $\mathrm{Cu}^{2+}(30 \mathrm{mg} / \mathrm{l})$ with different initial $\mathrm{pH}$ value. The sample $\mathrm{pH}$ was adjusted to the desired value with hydrochloric acid (or nitric acid) or sodium hydroxide aqueous solution. The bottles were agitated at $200 \mathrm{rpm}$ using a mechanical shaker for $8 \mathrm{~h}$. After filtration, the metal ions concentration in the filtrate and initial concentration were determined by atomic adsorption spectrophotometer and the adsorption capacities were calculated as follows:

$q=\frac{\left(C_{0}-C\right) V}{m}$

where $q$ is the adsorption capacities of chitosan derivatives ( $\mathrm{mg}$ metal ion/g adsorbent), $V$ is the volume of metal ion solution (1), $C_{0}$ is the concentration of metal ion before adsorption $\left(\mathrm{mg} \mathrm{l}^{-1}\right), C$ is the concentration of metal ion after adsorption $\left(\mathrm{mgl}^{-1}\right)$, and $m$ is the weight of chitosan derivatives $(\mathrm{g})$.

The effect of initial concentration of the metal ion on the uptake by alginate/P-chitin blend films was carried out by placing $50 \mathrm{mg}$ of alginate/P-chitin blend films in a series of flasks containing $25 \mathrm{ml}$ of aqueous solution of metal ions at definite concentrations and $\mathrm{pH}$ 5.0. The contents of the flasks were equilibrated on the shaker at $200 \mathrm{rpm}$ for $8 \mathrm{~h}$. After the equilibration, the metal ions concentration in the filtrate was determined by atomic adsorption spectrophotometer.

The effect of equilibration time on the uptake of $\mathrm{Ni}^{2+}, \mathrm{Zn}^{2+}$ and $\mathrm{Cu}^{2+}$ by alginate/P-chitin blend films was investigated using a batch method. A $50 \mathrm{mg}$ of alginate/P-chitin blend films was placed in a flask containing $25 \mathrm{ml}$ of aqueous solution of metal ions $(30 \mathrm{mg} / \mathrm{l})$ at $\mathrm{pH} 5.0$. The contents of the flask were equilibrated on a shaker at $200 \mathrm{rpm}$ for various time intervals. After the equilibration time, the metal ions concentration of the solution was detected.

\subsection{Measurements}

The IR spectra of the films were recorded in a PerkinElmer FT-IR 2000 series spectrophotometer at room temperature. The surface 


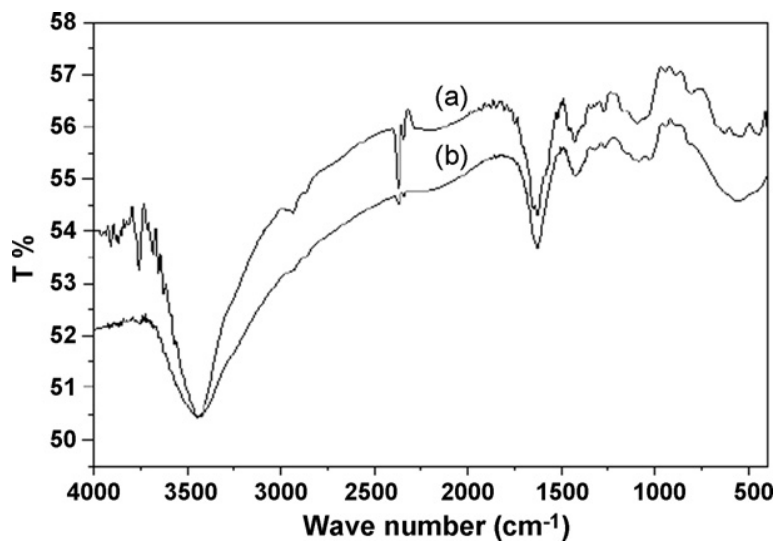

Fig. 2. FT-IR Spectra of (a) alginate and (b) alginate/P-chitin blend film.

morphology of films was analyzed by scanning electron microscopy (SEM) by using JEOL JSM-6700 microscope.

\section{Results and discussion}

\subsection{FT-IR spectra of alginate/P-chitin blend films}

Fig. 2 shows the FT-IR spectra of the pure and blend films in the wavelength ranges of $4000-400 \mathrm{~cm}^{-1}$. The characteristic peak of $\mathrm{P}$-chitin was observed at 3445 and $570 \mathrm{~cm}^{-1}$ are due to the $\mathrm{P}-\mathrm{OH}$ group. On the other hand, the bands of alginate was appeared at $3500 \mathrm{~cm}^{-1}$ for the hydroxyl groups and at 1624 and $1433 \mathrm{~cm}^{-1}$ for the asymmetric $-\mathrm{COO}^{-}$stretching vibration and symmetric $-\mathrm{COO}^{-}$ stretching vibration, respectively. The FT-IR results indicated that the alginate and P-chitin are blended well.

\subsection{Bioactivity studies of alginate/P-chitin blend films}

\subsubsection{Characterization by SEM}

Fig. 3 shows the FE-SEM of the alginate/P-chitin blend films after 7, 14 and 21 days. The membranes formed calcium phosphate apatite layer on the surface after immersion in the SBF, and these deposits grew in size with increasing soaking time. This indicates that these deposits are from crystalline apatite. These SEM results showed that alginate/P-chitin blend films can induce apatite formation in the body environment. Thus the films are having the bioactivity properties and hence they can be used for tissue engineering applications.

\subsubsection{Characterization by FT-IR}

FTIR spectrum reveals (Fig. 4) the apatite nature of the mineral layer previously observed by SEM. The intense bands at 1036,636 , 624 and $540,535 \mathrm{~cm}^{-1}$ are due to the $\mathrm{PO}_{4}$ vibrations [17-20]. In addition, peaks at 1425 and $825 \mathrm{~cm}^{-1}$ were also observed. These peaks are referring the formation of apatite [16-20]. Thus, these results provide strong evidence that HAP crystals were formed on the alginate/P-chitin blend films.

\subsection{Metal adsorption studies}

The $\mathrm{pH}$ values selected in the experiments were prior to the precipitation limit of each metal ion ( $\mathrm{pH} 7,6$ and 7 for $\mathrm{Ni}^{2+}, \mathrm{Cu}^{2+}$ and $\mathrm{Zn}^{2+}$, respectively). As shown in Fig. 5, the higher uptake capacity was achieved at higher $\mathrm{pH}$ values. The observed lower uptake in an acidic medium may be attributed to the partial protonation of the active groups and the competition of $\mathrm{H}^{+}$with metal ions for adsorption sites on the alginate/P-chitin blend films. At $\mathrm{pH}<2$, no appreciable uptake was detected for $\mathrm{Ni}^{2+}, \mathrm{Zn}^{2+}$ and $\mathrm{Cu}^{2+}$ ions.
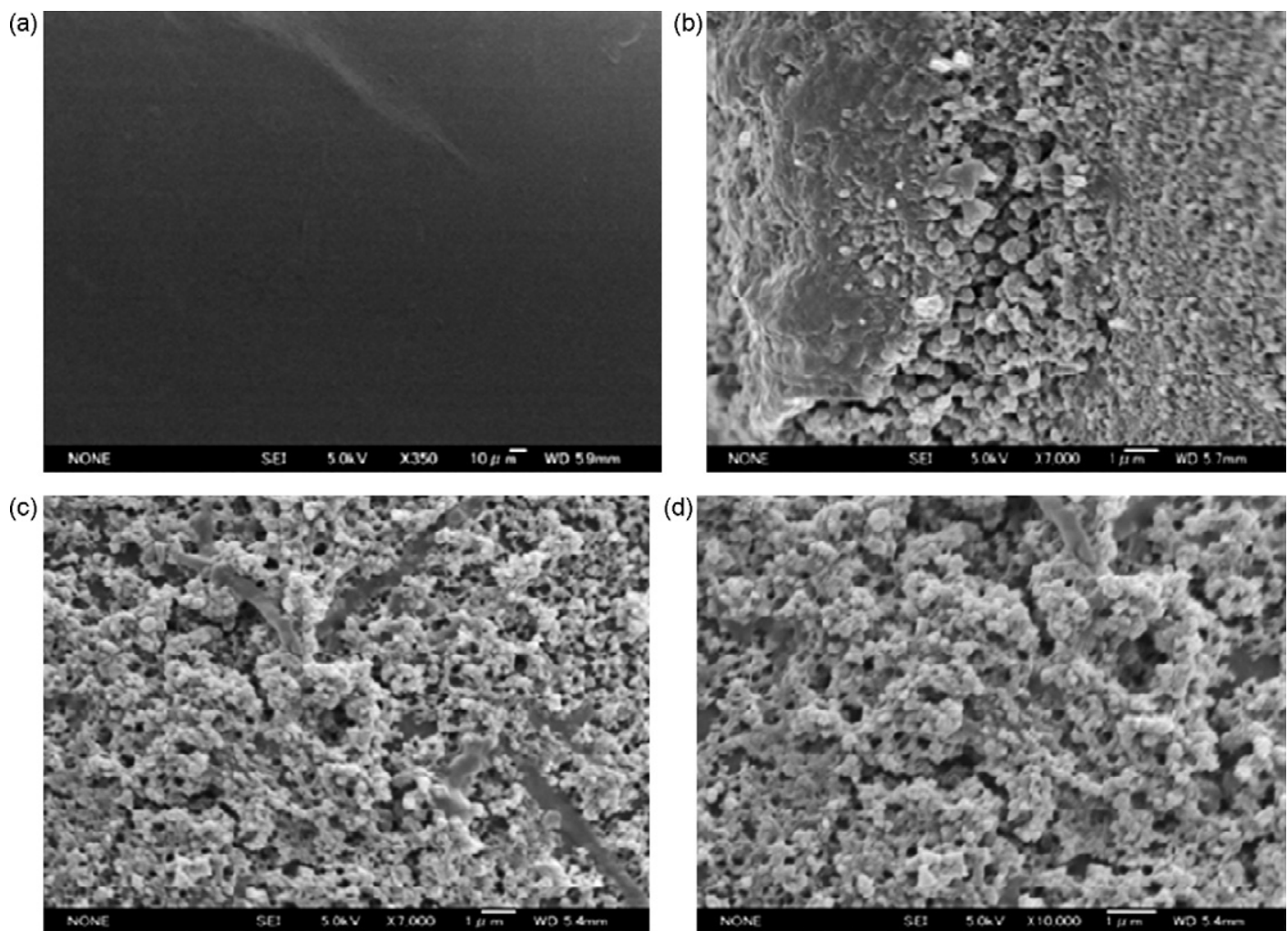

Fig. 3. SEM images of alginate/P-chitin blend (a) 0 control, (b) 14 (c) and (d) 21 days after immersing in SBF. 


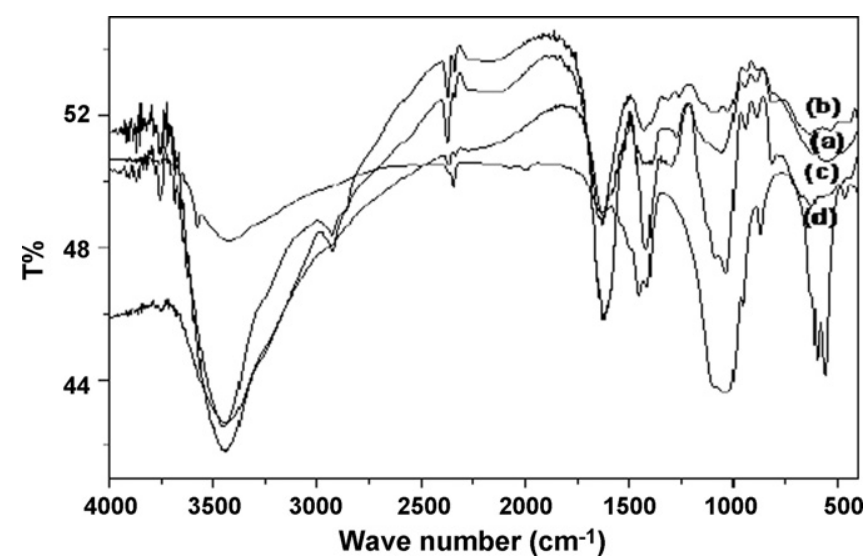

Fig. 4. FT-IR spectra of (a) alginate/P-chitin films after 14 days in SBF, (b) alginate/Pchitin blend film, (c) alginate/P-chitin films after 21 days in SBF and (d) hydroxy apatite.

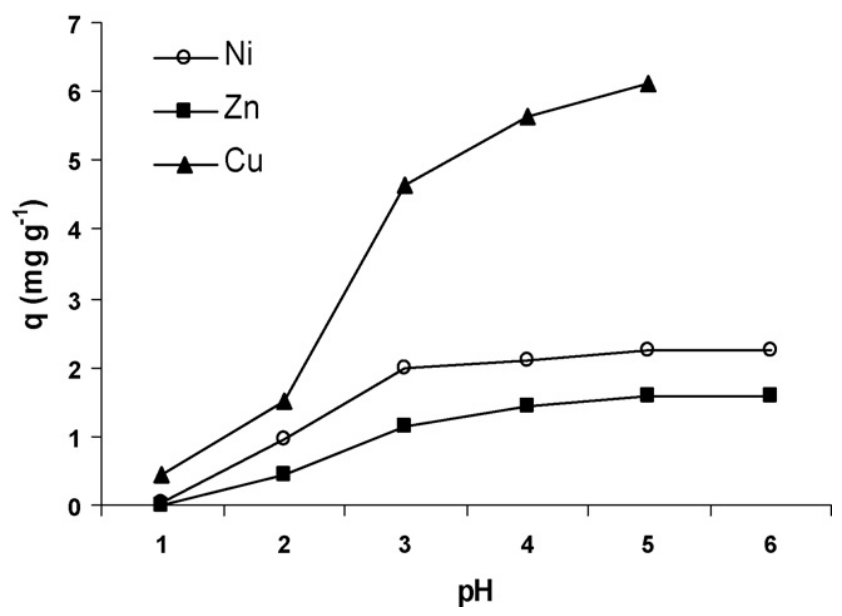

Fig. 5. Effect of $\mathrm{pH}$ on the uptake of $\mathrm{Ni}^{2+}, \mathrm{Zn}^{2+}$ and $\mathrm{Cu}^{2+}$ by alginate/P-chitin blend films (metal ion concentration: $30 \mathrm{mg} / \mathrm{l}$, adsorbent dose: $2 \mathrm{~g} / \mathrm{l}$ ).

\subsubsection{Effect of initial concentration of metal ions}

Fig. 6 shows the uptake of $\mathrm{Ni}^{2+}, \mathrm{Zn}^{2+}$ and $\mathrm{Cu}^{2+}$ on alginate/Pchitin blend films at the natural $\mathrm{pH}$. The uptake of three metal ions on alginate/P-chitin blend films increases as the initial concentration increases until they reached a plateau. At the plateau region,

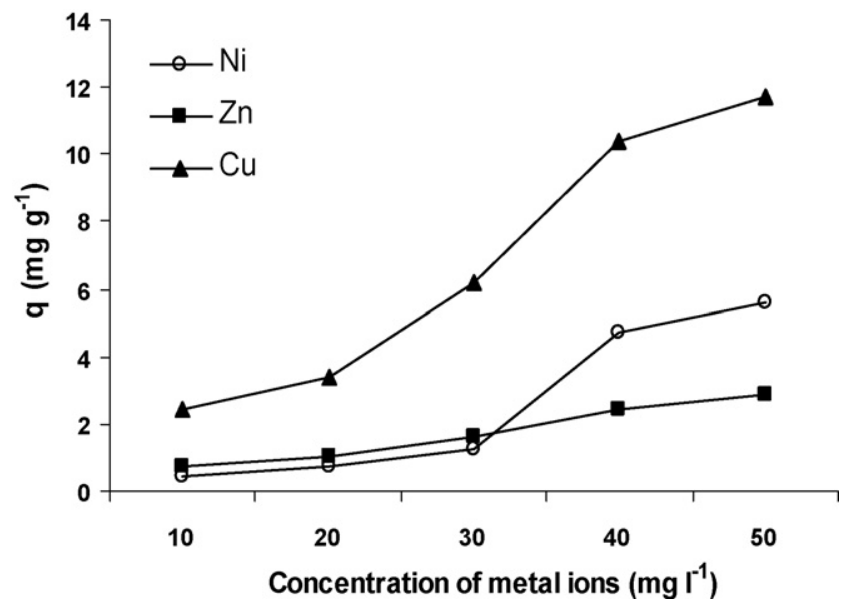

Fig. 6. Effect of initial concentration on the uptake of $\mathrm{Ni}^{2+}, \mathrm{Zn}^{2+}$ and $\mathrm{Cu}^{2+}$ by alginate/P-chitin blend films ( $\mathrm{pH}$ : 5.0, adsorbent dose: $2 \mathrm{~g} / \mathrm{l}$ ).

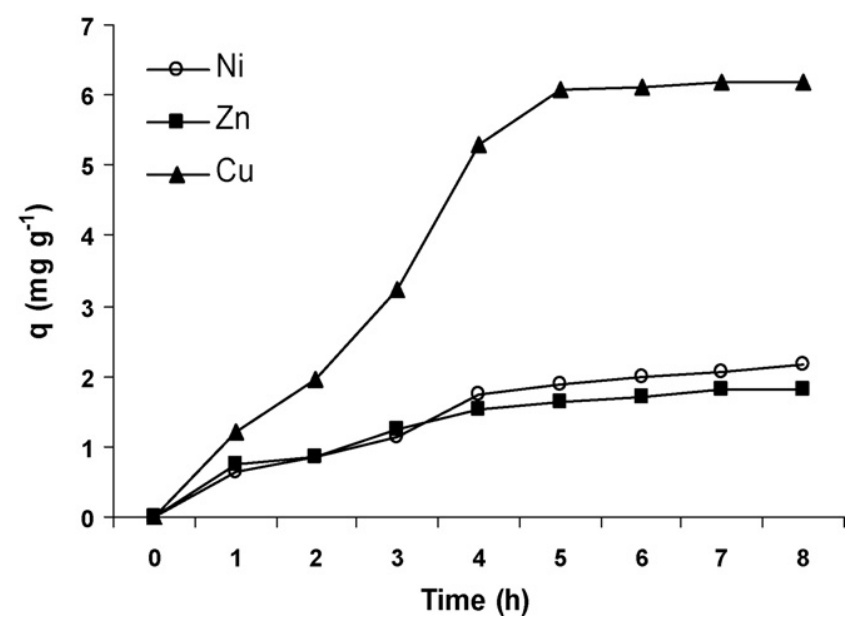

Fig. 7. Influence of contact time on the uptake of $\mathrm{Ni}^{2+}, \mathrm{Zn}^{2+}$ and $\mathrm{Cu}^{2+}$ by alginate/Pchitin blend films (metal ion concentration: $30 \mathrm{mg} / \mathrm{l}, \mathrm{pH} 5.0$, adsorbent dose: $2 \mathrm{~g} / \mathrm{l}$ ).

the maximum uptake values of $\mathrm{Ni}^{2+}, \mathrm{Zn}^{2+}$ and $\mathrm{Cu}^{2+}$ on alginate/Pchitin blend films are 5.67, 2.85 and $11.7 \mathrm{mg} / \mathrm{g}$, respectively.

\subsubsection{Adsorption kinetics}

Simple batch kinetic experiment of alginate/P-chitin blend films for $\mathrm{Ni}^{2+}, \mathrm{Zn}^{2+}$ and $\mathrm{Cu}^{2+}$ ion adsorption was conducted (Fig. 7). It could be seen that the adsorption of alginate/P-chitin blend films for these three metal ions was in high speed. Further, the experimental results suggest that the amount of $\mathrm{Ni}^{2+}, \mathrm{Zn}^{2+}$ and $\mathrm{Cu}^{2+}$ adsorbed $(\mathrm{mg} / \mathrm{g})$ increased with increasing contact time and reached equilibrium at $5 \mathrm{~h}$ for $\mathrm{Cu}^{2+}$ and $4 \mathrm{~h}$ for $\mathrm{Ni}^{2+}$ and $\mathrm{Zn}^{2+}$. The heavy metal uptake potential may indicate that most of the active sites of alginate/P-chitin blend films are exposed for interaction with the metal ions.

\section{Conclusions}

Alginate/P-chitin blend films were prepared by mixing of alginate and P-chitin in water and then cross-linked with $\mathrm{CaCl}_{2}$ solution. The SEM and FT-IR studies showed that alginate/P-chitin blend films are bioactive. At pH 5.0 the maximum adsorption capacity of alginate/P-chitin blend films for $\mathrm{Ni}^{2+}, \mathrm{Zn}^{2+}$ and $\mathrm{Cu}^{2+}$ was found to be 5.67, 2.85 and 11.7, respectively. Further, the amount of $\mathrm{Ni}^{2+}$, $\mathrm{Zn}^{2+}$ and $\mathrm{Cu}^{2+}$ adsorbed $(\mathrm{mg} / \mathrm{g})$ increased with increasing contact time and reached equilibrium at $5 \mathrm{~h}$ for $\mathrm{Cu}^{2+}$ and $4 \mathrm{~h}$ for $\mathrm{Ni}^{2+}$ and $\mathrm{Zn}^{2+}$. We predict that these novel alginate/P-chitin blend films may have potential applications in environmental areas, and for the removal of $\mathrm{Ni}^{2+}, \mathrm{Zn}^{2+}$ and $\mathrm{Cu}^{2+}$ from water and wastewater. These results also indicated that these films may be very useful for drug delivery, tissue engineering and other environmental applications.

\section{Acknowledgements}

One of the authors R. Jayakumar is grateful to the Japan Society for the Promotion of Science (JSPS), Japan for awarding of JSPS postdoctoral research fellowship (FY 2005-2006) to carry out research in Japan. This research was partly supported by the Grant-in-Aid for JSPS Fellows relating to JSPS Post-doctoral Fellowship for Foreign Researchers (Grant No. 17.05405) from JSPS.

\section{References}

[1] W.R. Gombotz, S.F. Wee, Adv. Drug Deliv. Rev. 31 (1998) 267-285.

[2] J. Dusseault, F.A. Leblond, R. Robitaille, G. Jourdan, G. Biomater. 26 (2005) 1515-1522. 
[3] S. Hirano, C. Itakura, H. Seino, Y. Akiyama, I. Nonaka, N. Kanbara, T. Kawakami, J. Agric. Food Chem. 38 (1990) 1214-1217.

[4] K. Nishimura, S.I. Nishimura, N. Nishi, F. Murata, Y. Tone, S. Tokura, I. Azuma, Vaccine 3 (1985) 379-385

[5] S. Tokura, S.I. Nishimura, N. Nishi, Polym. J. 15 (1983) 597-602.

[6] N. Nishi, A. Ebina, S.I. Nishimura, A. Tsutsumi, O. Hasegawa, S. Tokura, Int. J. Biol. Macromol. 8 (1986) 311-317.

[7] A. Tsutsumi, S. Sasajima, T. Hideshima, N. Nishi, S.I. Nishimura, S. Tokura, Polym. J. 18 (1986) 509-511.

[8] R. Jayakumar, R.L. Reis, J.F. Mano, E-Polymers 035 (2006).

[9] R. Jayakumar, N. Nwe, S. Tokura, H. Tamura, Int. J. Biol. Macromol. 42 (2007) 175-181.

[10] R. Jayakumar, M. Prabaharan, R.L. Reis, J.F. Mano, Carbohydr. Polym. 62 (2005) $142-158$.

[11] R. Jayakumar, H. Tamura, Asian Chitin J. 2 (2006) 61-68.
[12] R. Jayakumar, H. Tamura, Asian Chitin J. 2 (2006) 91-96.

[13] R. Jayakumar, H. Tamura, Polym. Preprints 55 (2006) 2101.

[14] R. Jayakumar, N. Selvamurugan, S.V. Nair, S. Tokura, H. Tamura, Int. J. Biol. Macromol. 43 (2008) 221-225.

[15] R. Jayakumar, T. Egawa, T. Furuike, S.V. Nair, H. Tamura, Polym. Eng. Sci. (in press).

[16] K. Hato, T. KokuboT, T. Nakamura, T. Yamamura, J. Am. Ceram. Soc. 78 (1995) 1049-1053.

[17] F. Chen, Z.C. Wang, C.J. Lin, Mater. Lett. 57 (2002) 858-861

[18] L. Kong, Y. Gao, G. Lu, Y. Gong, N. Zhao, X. Zhang, Eur. Polym. J. 42 (2006) 3171-3179.

[19] Y. Maeda, R. Jayakumar, H. Nagahama, T. Furuike, H. Tamura, Int. J. Biol. Macromol. 42 (2008) 463-467.

[20] K. Madhumathi, N.S. Binulol, H. Nagahama, H. Tamura, K.T. Shalumon, N. Selvamurugan, S.V. Nair, R. Jayakumar, Int. J. Biol. Macromol. (in press). 